Studia Judaica 21 (2018), nr 2 (42), s. 299-331

doi:10.4467/24500100STJ.18.014.10265

Maria Misztal

\title{
Mojżesz Merin - zbawca, kolaborant czy zagubiony człowiek?
}

\author{
MOSHE MERIN: SAVIOR, COLLABORATOR OR AN ASTRAY MAN?
}

\begin{abstract}
In January 1940, Moshe Merin became the Head of the Jewish Council of Elders of Eastern Upper Silesia. At this point, the community of Jews amounted to almost 100,000 members. Merin actively promoted his major concept of "survival by work." He believed that only working for the Third Reich combined with obedience and subordination toward the aggressor can guarantee Jewish survival. This policy arose objections, especially among Jewish youth involved in the resistance movement. Until mid-1942 Merin was an influential figure. His wide contacts with the Nazis and relatively good living conditions of Jews in Eastern Upper Silesia dismissed alleged reasons for mutiny. Therefore, during the first two years of the war, the Jewish Council of Elders of Eastern Upper Silesia enjoyed a lot of success. The situation changed in 1943 when the Nazis created ghettos and started forced deportations to KL Auschwitz. The Jewish Council stopped functioning when Moshe Merin and his main associates were deported to the death camp.
\end{abstract}

Keywords: Moshe Merin, Jewish Council, Eastern Upper Silesia, forced work, resistance movement, ghettos, death camp.

Słowa kluczowe: Mojżesz Merin, Rada Żydowska, Wschodni Górny Śląsk, praca przymusowa, ruch oporu, getta, obóz śmierci.

Z okazji szóstej rocznicy objęcia przez NSDAP władzy w Niemczech Adolf Hitler wygłosił 30 stycznia 1939 r. wiekopomne przemówienie:

Dziś pragnę powiedzieć jeszcze jedno, co być może zapadnie w pamięć nie tylko nam - Niemcom: wiele razy byłem w błędzie i zazwyczaj mnie wyśmiewano. W cza- 
sie mojej walki o władzę naród żydowski zareagował śmiechem na moje proroctwa, iż pewnego dnia stanę na czele państwa i całego narodu oraz że rozwiążę między innymi problem żydowski. Sądzę, że od tamtego dnia ów odrażający śmiech Żydów niemieckich uwiązł im w gardle. Dziś pragnę znów być prorokiem: jeśli międzynarodowa finansjera żydowska, zarówno w Europie, jak i poza nią, jeszcze raz pogrąży narody w wojnie, nie skończy się to bolszewizacją ziemi, a przez to zwycięstwem żydostwa, lecz zagładą rasy żydowskiej w Europie! ${ }^{1}$

Ta wypowiedź wytyczyła kierunek przyszłej polityki III Rzeszy. Kierunek, którego efektem miała być całkowita eksterminacja ludności żydowskiej w Europie. Antysemickie działania na terenie państwa rządzonego przez Führera rozpoczęły się niemal natychmiast po zdobyciu przezeń pełni władzy. Przejmowanie należących do Żydów majątków, bojkotowanie ich sklepów, zakaz wykonywania przez nich wielu wolnych zawodów wszystko to doprowadziło do ich pauperyzacji i izolacji. Jesienią $1938 \mathrm{r}$. szef Służby Bezpieczeństwa (Sicherheitsdienst, SD) Reinhard Heydrich nakazał opuścić granice III Rzeszy polskim obywatelom żydowskiego pochodzenia. W nocy z 27 na 28 października przedstawiciele służb policyjnych deportowali ok. 17 tys. Żydów, lokując ich w przygranicznych miejscowościach ${ }^{2}$. Kilkanaście dni później przez całe Niemcy przetoczyła się fala pogromów, która przeszła do historii pod nazwą „Nocy Kryształowej" (Kristallnacht). W nocy z 9 na 10 listopada zamordowano ok. 40 osób, a tysiące zostało rannych. Spalono 191 synagog (niemieckiej straży pożarnej zabroniono interweniować), a 76 zrównano z ziemią․ Te działania były pokłosiem uchwalonych 15 września 1935 r. tzw. ustaw norymberskich, które zabraniały zawierania małżeństw i utrzymywania stosunków pozamałżeńskich między Żydami a obywatelami „krwi niemieckiej bądź pokrewnej”, zatrudniania w żydowskich domach służących „krwi niemieckiej bądź pokrewnej" poniżej 45 roku życia oraz wywieszania przez Żydów flagi niemieckiej ${ }^{4}$. Nie sprecyzowano jednak tych wszystkich pojęć, co uczyniono dopiero w następnych miesiącach w przepisach wykonawczych. W listopadzie mianowicie stwierdzono, że Żydem jest każdy, kto miał co najmniej trzech żydowskich dziadków. Mimo że w ustawach nie

${ }^{1}$ Franciszek Piper, Żydzi w KL Auschwitz, Oświęcim 2015, s. 266.

2 Anna Wolff-Powęska, „Noc kryształowa” - noc hańby, „Znak” 60 (2008), nr 12, http:// www.miesiecznik.znak.com.pl/6432008anna-wolff-poweskanoc-krysztalowa-noc-hanby/ [dostęp: 19 marca 2017].

${ }^{3}$ François de Fontette, Historia antysemityzmu, tłum. Maria Mendychowska, Mieczysław Mendychowski, Wrocław 1992, s. 105.

${ }^{4}$ Raul Hilberg, Zagłada Żydów europejskich, t. 1, thum. Jerzy Giebułtowski, Warszawa 2014, s. 71. 
nawoływano do bicia, szykanowania i mordowania ludności żydowskiej, dały one asumpt do działań będących zapowiedzią jej przyszłej zagłady.

Jednak przed wojną nikt - łącznie $\mathrm{z}$ dygnitarzami władz nazistowskich nie myślał jeszcze o fizycznym unicestwieniu ludności żydowskiej. Dopiero cytowana na wstępie niniejszego artykułu konstatacja Hitlera stanowiła przełom i uruchomiła potężną machinę administracyjną składającą się z setek agend i urzędów, tysięcy biurokratów i niezliczonych ustaw i dekretów, której celem było uczynienie „Judenfrei” - wolnymi od Żydów okupowanych w przyszłości przez III Rzeszę terenów. Holokaust - jak niezwykle trafnie ujął to Raul Hilberg - był ,jednym, wyspecjalizowanym działaniem administracyjnym”. Istotnym elementem tej „maszynerii zagłady”6 stały się „samorządy” żydowskie, które w praktyce realizowały polecenia władz niemieckich. Wszystko to wytworzyło wojenno-okupacyjną praktykę realizowaną w Europie Środkowo-Wschodniej.

\section{„Samorządy” żydowskie}

1 września 1939 r. wybuchła wojna. Dla mieszkańców Polski był to początek kilkuletniej gehenny. Wyznacznikiem codzienności stały się przerażenie, strach, smutek i żałoba. Młodzi ludzie urodzeni w 1918 r. lub później po raz pierwszy znaleźli się w relacji okupant-okupowani. Starsi mieli doświadczenie podległości jeszcze z okresu zaborów, niemniej nie było ono naznaczone takim okrucieństwem. Z czasem coraz wyraźniej stał się widoczny zanik więzi międzyludzkich, upadek wartości czy destrukcja moralna. Postawy, które podczas pokoju były nie do pomyślenia, stały się akceptowalne, a nieraz nawet i pożądane. O to chodziło Niemcom, którzy parli na wschód z myślą uczynienia z tej części Europy przestrzeni życiowej dla „rasy panów” (Lebensraum). Chcieli się pozbyć stąd „podludzi”, zwłaszcza Żydów, a obojętna, niejednokrotnie nawet przychylna dla ich zbrodniczych planów postawa otoczenia bardzo przybliżała ich do tego celu.

Ziemie zajęte przez Niemców zostały podzielone na podstawie dekretów z 8 i 12 października 1939 r. na tereny włączone bezpośrednio do III Rzeszy i Generalne Gubernatorstwo. Do tych pierwszych wcielono województwa: poznańskie, pomorskie, śląskie, większą część łódzkiego,

5 Tamże, s. 56.

${ }^{6}$ Pojęcie również użyte przez Raula Hilberga w tym samym opracowaniu. 
część krakowskiego, warszawskiego i kieleckiego. Powstały cztery okręgi administracyjne: Prusy Wschodnie, Prusy Zachodnie-Gdańsk, Okręg Śląski i Okręg Poznański (od 29 stycznia 1940 r. - Okręg Kraju Warty). Ziemie włączone do Rzeszy zamieszkiwało 8,9 mln Polaków, ponad 600 tys. Żydów i niespełna 600 tys. Niemców? . Natomiast Generalne Gubernatorstwo podzielono na cztery dystrykty: krakowski, warszawski, radomski i lubelski. Po napaści Niemiec na ZSRR w czerwcu 1941 r. powstał następny, obejmujący Galicję Wschodnią (nazywany galicyjskim lub lwowskim).

Na wszystkich okupowanych przez Niemców obszarach tworzono Rady Żydowskie - Judenraty. Pierwsze powołano na przełomie września i października 1939 r. na mocy telefonogramu szefa Głównego Urzędu Bezpieczeństwa Rzeszy (Reichssicherheitshauptamt, RSHA), wspomnianego już Reinharda Heydricha. 21 września 1939 r. trafił on do dowódców Oddziałów Operacyjnych Służby Bezpieczeństwa i Policji Bezpieczeństwa (Einsatzgruppen des Sicherheitsdienstes und der Sicherheitspolizei). W dokumencie tym Heydrich nakazywał tworzenie „Rad Starszych”, które miały reprezentować społeczności żydowskie na poszczególnych terenach. $\mathrm{Na}$ ich czele stawiano często przedwojennych radnych lub prezesów gmin oraz osoby zajmujące eksponowane stanowiska w organizacjach społecznych i religijnych ${ }^{8}$. Teoretycznie Judenraty miały być samorządami, a ich członkowie - przedstawicielami ludności żydowskiej w konkretnych gminach i ich reprezentantami w kontaktach z okupantem. W rzeczywistości były one jednak organami administracyjnymi w pełni sterowanymi przez władze niemieckie. Powstawały wszędzie tam, gdzie istniały skupiska żydowskie. W zależności od ich wielkości Niemcy wyznaczali od 6 do 24 członków rady (wyjątkiem był Judenrat w Łodzi, w którego skład wchodziły 32 osoby, ponieważ w pierwszych miesiącach 1940 r. w tamtejszym getcie przebywało już ponad 160 tys. ludzi) ${ }^{9}$.

Na terytorium Generalnego Gubernatorstwa Rady Żydowskie w większych miastach podlegały starostom miejskim (Stadthauptmänner), a w mniejszych - starostom powiatowym (Kreishauptmänner). Natomiast na obszarach wcielonych bezpośrednio do III Rzeszy rady te w dużych

\footnotetext{
7 Antony Polonsky, Dzieje Żydów w Polsce i Rosji, tłum. Mateusz Wilk, Warszawa 2014, s. 444 .

Hilberg, Zagłada Żydów europejskich..., s. 251.

Andrzej Żbikowski, Zagłada Żydów polskich, [w:] Historia Żydów. Dzieje narodu od Abrahama do Państwa Izrael. Żydzi w Polsce. 1000 lat wspólnych losów, red. Leszek Będkowski, Anita Brzostowska, Warszawa 2014, s. 348-349.
} 
miastach zależne były od burmistrzów (Bürgermeister), w małych miasteczkach i na wsi zaś od starostów (Landräte) ${ }^{10}$.

W ciągu pierwszych trzech lat wojny (gdy plan eksterminacji nie był jeszcze zatwierdzony) czołowi przedstawiciele Judenratów żyli w zgoła odmiennych warunkach niż setki tysięcy ich rodaków cierpiących z powodu wszechobecnego terroru, głodu i chorób. Mordechaj Chaim Rumkowski (nazywany „królem żydowskim”), przewodniczący Rady Starszych w getcie łódzkim, uwielbiał przepych i wystawne życie. Był megalomanem: drukował znaczki pocztowe ze swoją podobizną, w przemówieniach bardzo często używał takich zwrotów, jak „moi Żydzi”, „moje dzieci”, „moje fabryki”"11. Również w Krakowie na pierwszy rzut oka widać było ogromny kontrast między luksusowym życiem członków Rady Żydowskiej a tysiącami ludzi próbujących zdobyć kawałek chleba, aby przeżyć kolejny dzień.

Wspomniany już Mordechaj Chaim Rumkowski z Łodzi, a także Adam Czerniaków z Warszawy, Efraim Barasz z Białegostoku, Marek Biberstein z Krakowa czy Mojżesz Merin z Sosnowca i inni, obejmując stanowiska przywódców Judenratów, musieli się liczyć nie tylko z wielką odpowiedzialnością, ale też ze skrajnymi reakcjami swoich rodaków. Na szczególną uwagę zasługuje Mojżesz Merin, który w latach 1940-1943 był przewodniczącym Centrali Żydowskich Rad Starszych na Wschodnim Górnym Śląsku (Zentrale der Jüdischen Ältestenräte in Ostoberschlesien). Jego pozycja wyraźnie wyróżniała się spośród pozostałych liderów Rad Żydowskich (do 1942 r. jako jedyny miał do dyspozycji samochód i kierowcę), w związku z czym w pewnym momencie zapragnął być zwierzchnikiem ludności żydowskiej nie tylko na podległym mu obszarze, lecz także na pozostałych ziemiach polskich włączonych do III Rzeszy oraz na terytorium Generalnego Gubernatorstwa, a nawet Protektoratu Czech i Moraw.

Zanim jednak prześledzimy błyskawiczną karierę Mojżesza Merina (i jego równie szybki upadek) oraz zapoznamy się z głównymi założeniami prowadzonej przezeń polityki, konieczna jest prezentacja terenu, na jakim przyszło mu działać.

W listopadzie 1939 r. rejony południowo-zachodniej części przedwojennego województwa kieleckiego (m.in. Zagłębie Dąbrowskie) oraz obszary zachodniej Małopolski (w tym Żywiecczyzna i ziemia oświęcimska) stały się częścią ziem wcielonych do III Rzeszy, a administracyjnie znalazły

${ }^{10}$ Hilberg, Zagłada Żydów europejskich..., s. 254.

11 Tamże. 
się w obrębie nowo utworzonej rejencji katowickiej (Regierungsbezirk Kattowitz), stanowiącej część prowincji śląskiej (Provinz Schlesien) ${ }^{12}$.

Rejencja katowicka miała wówczas wyjątkowy status. Łączyła ona przygraniczne tereny niemieckiego Górnego Śląska, Zagłębie Dąbrowskie i Zagłębie Chrzanowsko-Jaworznickie. Rejencję zamieszkiwało niespełna 2,5 mln ludności, w tym blisko 100 tys. Żydów. W samym Zagłębiu Dąbrowskim było ich prawie 70 tys., skoncentrowanych głównie w kilku miastach: Będzinie (ok. 25 tys.), Sosnowcu (22,5-23 tys.), Zawierciu (ponad 6 tys.) i Dąbrowie Górniczej (ponad 5,5 tys.) ${ }^{13}$. Jednak szczególne traktowanie tej rejencji przez okupanta nie wynikało z liczebności ludności żydowskiej na tym obszarze (wszak więcej jej było w Generalnym Gubernatorstwie), lecz z jego potencjału gospodarczego, który w całości miał służyć celom niemieckiego przemysłu wojennego. W tym kontekście mieszkający tam Żydzi stanowili ogromny rezerwuar darmowej siły roboczej, co w początkowej fazie wojny gwarantowało im zdecydowanie lepsze warunki życia w porównaniu z tymi, w jakich znaleźli się ich pobratymcy mieszkający w innych częściach Polski. Mojżesz Merin uważał siebie za ojca tego „sukcesu”, co było niewątpliwie nadużyciem z jego strony. Gdyby ziemie te nie były tak rozwinięte gospodarczo i nie miały infrastruktury sprzyjającej prowadzeniu wojny, to żadne starania przewodniczącego Centrali Żydowskich Rad Starszych (dalej: CŻRS) nie gwarantowałyby ludności żydowskiej bezpieczeństwa. Jednak to właśnie on, a nie ktoś inny w styczniu 1940 r. został mianowany przewodniczącym CŻRS na Wschodnim Górnym Śląsku. Na tę funkcję powołał go komisarz generalny Hans Dreier, kierownik referatu ds. żydowskich w katowickim Gestapo ${ }^{14}$. Od tego momentu Merin był odpowiedzialny za realizację wszelkich działań

12 Taki podział administracyjny wynikał z dekretu Adolfa Hitlera z 8 października 1939 r. W styczniu 1941 r. Führer wydał kolejne rozporządzenie, zgodnie z którym prowincję śląską podzielono na dwie części: górnośląską ze stolicą w Katowicach i dolnośląską ze stolicą we Wrocławiu. W skład tej pierwszej weszły rejencje katowicka i opolska, natomiast w skład drugiej - rejencje wrocławska i legnicka.

${ }^{13}$ Są to dane pochodzące z początków 1940 r. Zob. Fredka Mazja Oxenhaendler, Avihu Ronen-Klinger, Z historii Żydów na Wschodnim Górnym Śląsu. Holocaust w Zagłębiu, „Ekspres Zagłębiowski” (1994), nr 1/2, s. 12; Wstęp do inwentarza zespołu akt Vorstand der Jüdischen Interessenvertretung in Bendsburg (Zarząd Przedstawicielstwa Ludności Żydowskiej w Będzinie) 1939-1945, oprac. Anita Chodkowska, Dorota Zamojska, 2006, Archiwum Żydowskiego Instytutu Historycznego [dalej: AŻIH], sygn. 212, k. 3.

${ }^{14}$ Aleksandra Namysło, Zanim nadeszła Zagłada... Położenie ludności żydowskiej w Zagłębiu Dąbrowskim w okresie okupacji niemieckiej / Before the Holocaust Came... The Situation of Jews in Zaglembie during the German Occupation, thum. Alicja Cholewa-Zawadzka, Jana Dębska, Katowice 2009, s. 50. 
dotyczących społeczności żydowskiej na podległym mu obszarze. Niemcy dobrze go znali, ponieważ tuż po zajęciu przez nich Sosnowca 4 września 1939 r. negocjował z nimi kwestię uwolnienia Żydów przetrzymywanych w hali fabryki Schöna, znajdującej się przy ulicy 1 Maja. Ponadto jeszcze przed wojną był członkiem zarządu Wyznaniowej Gminy Żydowskiej ${ }^{15}$.

\section{Przewodniczący CŻRS}

Nie wszystkie środowiska żydowskie zaaprobowały ten wybór. Gminy górnośląskie nigdy nie uznały jego zwierzchnictwa i podejmowały decyzje samowolnie - bez konsultacji z Centralą Żydowskich Rad Starszych Wschodniego Górnego Śląska. W najważniejszych kwestiach kontaktowały się z gminą bytomską, czyli z przedstawicielstwem Żydów z tzw. Altreichu' ${ }^{16}$, a Żydowski Komitet w Będzinie podporządkował się CŻRS dopiero po bezpośredniej interwencji Gestapo. Naciski wywierane na reprezentantów ludności żydowskiej Będzina i bezkompromisową postawę Merina zapamiętał jeden z nielicznych ocalałych tamtejszych Żydów - Jakub Sender. W jego wspomnieniach, znajdujących się w zbiorach Archiwum Żydowskiego Instytutu Historycznego, można odnaleźć obszerną relację na temat powyższego konfliktu. Sender tak go opisał:

Moniek Meryn [Merin - przyp. M.M.] [...] oświadczył, że jest upoważniony przez Gestapo do zorganizowania gmin żydowskich na całym terenie Wschodniego Górnego Śląska, do którego jest włączane Zagłębie Dąbrowskie, a więc i Będzin. Od razu też zażądał, aby mu powierzono kierownictwo Komitetu Żydowskiego. Po krótkiej naradzie całego Komitetu powiedziano mu, żeby po kilku dniach zgłosił się po decyzję. Komitet bowiem stał na stanowisku, ażeby grać na zwłokę i nie oddawać losu mieszkańców w ręce osoby nieznanej. Po kilku dniach [Merin - przyp. M.M.] zgłosił się powtórnie, zażądał natychmiastowego zwołania Komitetu, wobec którego przeczytał list rzekomo od Gestapo, który upoważnia go do organizowania gmin żydowskich na wyżej wymienionym terenie. W treści listu była zawarta groźba dla Komitetu, że w razie nieposłuszeństwa wobec Meryna wynikną dla nich poważne i smutne konsekwencje. Komitet nie miał jednak zaufania do tego listu, bo M. Meryn nikomu nie chciał dać listu do ręki, tylko odczytał jego treść. Wobec tego Komitet nadal zajął stanowisko wstrzymujące się od decyzji. M. Meryn zorientował się w postępowaniu Komitetu będzińskiego. Po 2. dniach przybył z 3 oficerami Gestapo. Zwołano na ich żądanie cały Komitet, ustawiono w formie półkola

15 Natan Eliasz Szternfinkiel, Zagłada Żydów z Sosnowca, Katowice 1946, s. 10.

16 Aleksandra Namysło, Centrala Żydowskich Rad Starszych na Wschodnim Górnym Śląsk, [w:] Zagłada Żydów zagłębiowskich, red. Aleksandra Namysło, Będzin 2004, s. 49. 
wszystkich na sali posiedzeń Komitetu. Oficerowie Ci w jego obecności [Merina przyp. M.M.] oświadczyli, że w razie nieoddania kierownictwa Gminy Żydowskiej w ręce M. Meryna „da sind eurere Köpfe unser” [„,wasze głowy będą należeć do nas” - tłum. M.M.], wskazując szpicprutą na głowy zebranych członków Komitetu. Po ich odejściu było zebranie Komitetu, na którym M. Meryn objął kierownictwo jako ogólny zwierzchnik Żydów z Zagłębia ${ }^{17}$.

Jawnie występował przeciwko niemu również ortodoksyjny rabin Szaja Englard, skonfliktowany z nim od lat. Merin, podobnie jak zdecydowana większość członków CŻRS, uchodził przed wojną za zwolennika postępowego sosnowieckiego rabina Hagera, religijnego rywala Englarda.

Także wielu mieszkańców Zagłębia Dąbrowskiego, zwłaszcza młodych, wypowiadało się o Merinie negatywnie. Ann Kirschner, która w książce Listy z pudełka. Sekret mojej mamy opublikowała fragmenty kilkudziesięciu listów swojej matki Sally Kirschner (ur. w 1923 r. jako Sala Garncarz w Sosnowcu), ukazujących jej tułaczkę po obozach pracy przymusowej w latach 1940-1945, napisała, jak Sally zapamiętała Merina. Według niej był to:

Trzydziestosiedmioletni, niewysoki i zawsze spięty syjonista i pomniejszy polityk. Cieszył się wątpliwą reputacją jako rozwodnik i hazardzista, ambitny hochsztapler, nieustannie proszący o pożyczki lub przysługi ${ }^{18}$.

W jeszcze ostrzejszych słowach mówił o nim inny mieszkaniec Sosnowca, Dawid Fischer, który nazywał go „marną kreaturą, kobieciarzem, karciarzem i nicponiem" ${ }^{19}$. Nieco inaczej zapamiętał przewodniczącego Centrali urodzony 26 października 1923 r. w Zawierciu Artur Dimant (obecnie Ariel Yahalomi), który wraz z rodzicami (Leonem Dimantem i Sala z domu Federman) przeprowadził się do Sosnowca w 1933 r. W swoich wydanych kilkanaście lat temu wspomnieniach pt. Przeżłem... napisał o Merinie, że to: „inteligent przedwojenny, bywalec kawiarni, jednak ani wybitny tuz intelektualny, ani ważna persona"20.

17 Jakub Sender, Relacja, b.d., AŻIH, sygn. Relacje 301/1225, k. 3.

${ }_{18}$ Ann Kirschner, Listy z pudełka. Sekret mojej mamy, tłum. z języka angielskiego Barbara Gadomska, tłum. listów z języka jidysz i niemieckiego Aleksandra Geller, Warszawa 2008, s. 38.

${ }^{19}$ Dawid Fischer, Relacja, b.d., AŻIH, sygn. Relacje 301/1335, k. 3.

${ }^{20}$ Ariel Yahalomi, Przeżytem..., wyd. 3, Będzin 2014, s. 51. Po raz pierwszy książka została wydana w 2006 r., a jej uroczysta promocja miała miejsce 14 września 2007 r. w Miejskiej i Powiatowej Bibliotece Publicznej w Będzinie podczas obchodów V Dni Kultury Żydowskiej, odbywających się corocznie od 2003 r. W 2011 r. wspomnienia Ariela Yahalomiego w tłumaczeniu Ewy Doleckiej-Młoduchowskiej ukazały się w wersji anglojęzycznej pt. I Survived... 
Analizując te wypowiedzi, można z niemałą dozą prawdopodobieństwa stwierdzić, że objęcie przez Merina funkcji przewodniczącego CŻRS nie spowodowało jakichś istotnych zmian w postrzeganiu jego osoby. Już przed wojną cieszył się nie najlepszą opinią, a jego działania w latach okupacji hitlerowskiej wśród niektórych tylko spotęgowały te uczucia. Jednak nie brakowało i takich, którzy widzieli w nim szansę na ocalenie.

\section{Administracja żydowska}

Wbrew animozjom i antypatiom Merin szybko zorganizował sprawną administrację. W pierwszych miesiącach 1940 r. w głównej siedzibie CŻRS przy ul. Targowej 12 w Sosnowcu zatrudnionych było 17 osób, pół roku później - 50, a w połowie 1941 r. - 116 osób. W grudniu 1942 r. instytucja ta zatrudniała już 1700 pracowników i posiadała siedem departamentów: pracy, zdrowia, prawa, finansów, majątku, zarządzania i zaopatrzenia. Asystentką Merina została Fanny Czarna, która urodziła się w Bazylei i przez wiele lat mieszkała w Niemczech, w związku z czym pełniła także funkcję tłumaczki. Przewodniczący powołał również prezydium CŻRS, w którego skład wchodzili Wolf Śmietana, znany powszechnie jako „druga ręka Merina", Uszer Klajnberg i Chaim Merin (brat Mojżesza), który został następnie przewodniczącym Zarządu Przedstawicielstwa Ludności Żydowskiej w Będzinie (Vorstand der Jüdischen Interessenvertretung in Bendsburg). Nadzór nad koordynacją poszczególnych wydziałów Centrali sprawował sekretariat generalny kierowany przez Arona Lewensztajna ${ }^{21}$.

Wszystkie gminy podlegające Centrali wcielono w skład ośmiu inspektoratów powiatowych (Kreisinspektoraten), którymi zarządzali inspektorzy powiatowi. Do ich głównych zadań należało wykonywanie poleceń sosnowieckiego Judenratu w terenie, przeprowadzanie systematycznych kontroli poszczególnych zarządów gminnych i regularne informowanie CŻRS o ich rezultatach ${ }^{22}$.

W październiku 1940 r. CŻRS podlegało 96283 Żydów zamieszkujących w 34 gminach $^{23}$. W tym czasie Heinrich Himmler powołał Specjalnego Peknomocnika Reichsführera SS i Szefa Niemieckiej Policji do spraw Zatrudnienia Obcych Narodowości na Górnym Śląsku (Sonderbeauftragter des

${ }^{21}$ Andrzej Strzelecki, Zagłada Żydów z Zagłębia Dąbrowskiego w KL Auschwitz, Oświę$\operatorname{cim} 2014$, s. 45.

${ }_{22}$ Namysło, Centrala Żydowskich Rad Starszych..., s. 41.

${ }^{23}$ Wstęp do inwentarza... 
Reichsführers SS und Chef der Deutschen Polizei für fremdvölkischen Arbeitseinsatz in Oberschlesien). Został nim Albrecht Schmelt, który dotychczas pełnił funkcję prezydenta policji wrocławskiej ${ }^{24}$. Z czasem stał się on jedynym dysponentem żydowskiej siły roboczej na tym terenie (w lutym 1941 r. wprowadzono zakaz zatrudniania Żydów bez jego zezwolenia w sektorze prywatnym i publicznym). Jako pełnomocnik Himmlera stworzył sieć obozów pracy przymusowej dla ludności żydowskiej, od jego nazwiska nazwaną Organizacją Schmelt. Do obozów tych, zakładanych przy lub na terenie przedsiębiorstw odgrywających istotną rolę w niemieckiej gospodarce wojennej, kierowano zdolnych do pracy Żydów z całego Śląska, zarówno mężczyzn, jak i kobiety.

W latach 1940-1944 w rejencjach katowickiej i opolskiej funkcjonowały 93 obozy Organizacji Schmelt, w których przebywało ok. 50 tys. Żydów ${ }^{25}$. Ludność żydowska była kierowana również do pracy w miejscowych warsztatach i fabrykach, które niegdyś stanowiły jej własność, a po wybuchu II wojny światowej znalazły się w rękach zarządców niemieckich, tzw. Treuhänderów. Ich produkcja nastawiona była przede wszystkim na zaspokajanie potrzeb Wehrmachtu (przeważnie produkowano tam mundury i obuwie wojskowe). Oficjalnie zakłady te nazywano ,warsztatami zbiorczymi” (Sammelwerkstätten), potocznie zaś „szopami”26.

Przy CŻRS utworzono specjalny wydział pracy przymusowej (Arbeitseinsatzabteilung), któremu podlegał obóz przejściowy, tzw. Dulag (Durchgangslager). Umieszczano w nim Żydów przeznaczonych na wywózkę do obozów pracy. Funkcjonował również Zwilag (Zwischenlager), pozostający pod nadzorem milicji żydowskiej, w którym przetrzymywano członków rodzin osób ukrywających się przed wysyłką; ich najbliżsi doprowadzani byli tam w zastępstwie, jako tzw. Ersatz. Jeśli osoby pozostające w ukryciu nie ujawniły się, konsekwencję ponosili ich krewni, zarówno kilkuletnie dzieci, jak i starcy 27 .

Mojżesz Merin okazał się nieocenionym pomocnikiem Albrechta Schmelta, bo - jak zapamiętała Sally Kirschner vel Sala Garncarz - ,początkowo Schmelt niezbyt dobrze radził sobie z rozmieszczeniem ogromnej

${ }^{24}$ Strzelecki, Zagłada Żydów..., s. 40.

${ }_{25}$ Aleksandra Namysło, Postawy mieszkańców rejencji katowickiej wobec ludności żydowskiej, [w:] Polacy i Żydzi pod okupacja niemiecka 1939-1945. Studia i materiały, red. Andrzej Żbikowski, Warszawa 2006, s. 775.

${ }^{26}$ Strzelecki, Zagłada Żydów..., s. 42.

${ }^{27}$ Albert Nirensztain, Ruch oporu Żydów w Zagłębiu Dąbrowskim pod okupacja hitlerowska, „Kwartalnik Historii Żydów” (2001), nr 4, s. 593. 
siły roboczej"28, a świetnie w tej kwestii orientował się przewodniczący Judenratu. Ponadto kontakty między Merinem a Schmeltem dodatkowo ułatwiał fakt, iż główna siedziba Organizacji Schmelt - Dienstelle - również znajdowała się w Sosnowcu (w budynku przy Rathausstraße 6). Nawiązanie współpracy ze Specjalnym Pełnomocnikiem Reichsführera SS i Szefa Niemieckiej Policji do spraw Zatrudnienia Obcych Narodowości na Górnym Śląsku z pewnością decydująco wpłynęło na powstanie koncepcji „ocalenia przez pracę", która stała się filarem polityki Merina. Główne założenia tej koncepcji to bezwarunkowe podporządkowanie się poleceniom władz niemieckich i całkowita wobec nich uległość. Taka postawa miała zagwarantować Żydom ciągłą pracę na rzecz okupanta, a w konsekwencji - ukazanie ich jako niezbędnych robotników, zapewniających funkcjonowanie gospodarki niemieckiej.

Wcześniej zaznaczono, że to nie Merin zdołał przekonać okupantów do takiej polityki, eksploatację gospodarczą tego terenu mieli oni bowiem w planach przed utworzeniem Judenratu. Czy można krytykować go za jej wspieranie? „Produktywność” jako strategia postępowania i przeżycia miała dla Żydów w tamtym okresie pewien walor racjonalności. Poza tym nie tylko zagłębiowscy Żydzi wiązali z pracą nadzieję. Ludzie wyrzucani $\mathrm{z}$ domów i wywożeni z gett $\mathrm{w}$ bydlęcych wagonach modlili się o trafienie do obozu pracy. W warunkach II wojny światowej katorżnicza, niewolnicza praca fizyczna ponad siły oznaczała dla Żydów życie. „Pracuje” znaczyło tyle co „jestem użyteczny”, a skoro taki jestem, to mnie nie zabiją.

Przewodniczący CŻRS skupiał się nie tylko na realizowaniu założeń tej koncepcji, lecz także na utrudnianiu ludności żydowskiej kontaktów z „Aryjczykami”. Dotyczyło to przede wszystkim nielegalnego wspólnego handlu i korzystania przez Żydów z pomocy „obcych”. Jednak dużą przesadą byłoby twierdzenie, że kontakty między ludnością wyznania mojżeszowego i „Aryjczykami” przybrały masowy charakter. Handel był dla jednych i drugich okazją do robienia korzystnych interesów, a pomoc materialna i żywnościowa na większą skalę nie była potrzebna żydowskim mieszkańcom regionu ze względu na ich stabilną sytuację życiową, o czym będzie więcej w dalszej części tego tekstu²9.

28 Kirschner, Listy z pudetka..., s. 38.

29 Namysło, Postawy mieszkańców rejencji katowickiej..., s. 779. 


\section{„Ocalenie przez pracę"}

Merin lansował zatem politykę „ocalenia przez pracę”, w ówczesnej sytuacji wydawała się bowiem dość racjonalna, choć niepewna, zwłaszcza po pierwszych żydowskich doświadczeniach wojenno-okupacyjnych. Tymczasem Niemcy, czego dowodziły kolejne ich kroki, jednocześnie realizowali program „Vernichtung durch Arbeit”, czyli „wyniszczania przez pracę”. Żydzi z pracą wiązali nadzieję na przeżycie, natomiast dla ich oprawców była ona jedną z metod eksterminacji.

Oczywiście Merin nie znał tych planów, dlatego też z wielką gorliwością wypełniał polecenia Schmelta. Jednym z pierwszych jego obowiązków było zadbanie o przeprowadzenie dokładnego spisu ludności żydowskiej z podziałem na wiek, płeć i wykonywane zawody. Na murach, słupach i w witrynach sklepowych pojawiły się obwieszczania w trzech językach (niemieckim, polskim i jidysz), nakazujące Żydom zarejestrowanie się w siedzibie rady i grożące, że ci, którzy tego nie zrobią, utracą kartki żywnościowe i będą ścigani. Ann Kirschner, relacjonując wspomnienia matki, na wielu stronach wyeksponowała wątki dotyczące Merina. Sally podkreślała w nich, że przewodniczący CŻRS nie tylko pieczołowicie wypełniał polecenia Niemców, ale też niejednokrotnie sam wychodził $\mathrm{z}$ różnymi inicjatywami.

Po zakończeniu spisu Merin i jego pracownicy dopasowali listę Żydów do potrzeb Schmelta. Zrobiono wyjątek dla rodzin płacących podatek pogłówny, reszcie zaś Merin obiecał „góry złota” i bezpieczeństwo rodziny. Jego pracownicy liczyli ludzi, nie patrząc na konkretne nazwiska. Wkrótce dysponowali wystarczającą liczbą ochotników, by zaspokoić potrzeby organizacji. Większość z nich pochodziła z najbiedniejszych rodzin Sosnowca. Starając się jak najpilniej wypełnić rozkazy Schmelta, Merin wysłał pierwszych robotników do Niemiec co najmniej cztery tygodnie za wcześnie. Gdy w nocy dojechali na miejsce przeznaczenia, stwierdzili, że obóz ogranicza się właściwie do tablicy z jego nazwą; brakowało wody i sprzętu, a drewniane budynki, mające służyć za baraki, wciąż były w budowie. Merin nie odważył się zawrócić transportu, bo mogłoby to zniechęcić następnych ochotników. Przez wiele tygodni ludzie ci spali pod gołym niebem ${ }^{30}$.

Merin nieraz osobiście wizytował obozy, do których wywożeni byli jego rodacy. Ponieważ znaleźli się tam w ogromnej mierze z powodu jego

${ }^{30}$ Kirschner, Listy z pudetka ..., s. 39-40. 
działań, więc swoją obecnością bardzo często wzbudzał w nich agresję. Maria Adlerflügel, która od 1936 r. pracowała jako pielęgniarka w szpitalu żydowskim przy ul. Konrada 9 w Sosnowcu, w połowie 1940 r. została wysłana do obozu pracy znajdującego się w miejscowości Auenrode (obecnie Osiek Grodkowski) na terenie rejencji opolskiej. Przebywała tam do marca $1941 \mathrm{r}$. W swojej relacji wspomina o tym, jak na przybycie Merina zareagowali robotnicy znajdujący się w pobliskim obozie Geppersdorf (teraz Rzędziwojowice w gminie Niemodlin, województwo opolskie):

Wiem, że do pobliskiego obozu Geppelsdorf [pisownia oryginalna - przyp. M.M.] 10-15 km od nas przyjechał raz z ramienia Centrali Żyd[owskiej] w Sosnowcu Moniek Merin z jeszcze jednym (nazwiska nie pamiętam) i obozowcy zrobili mu straszną awanturę. Nasi obozowcy stykali się często na Baustelle [plac budowy autostrady - przyp. M.M.] z obozowcami z innych obozów pobliskich, jak np. Klein Mangersdorf ${ }^{31}$, Geppelsdorf, Gross Sarny [prawidłowa nazwa: Gross Sarne przyp. M.M.] $]^{32}$. Obozowcy z Geppelsdorf opowiedzieli naszym, że przyjęli Mońka Merina przekleństwami, mając do niego pretensje, że ich wysłał do obozu ${ }^{33}$.

CŻRS nałożyła na żydowskich mieszkańców Wschodniego Górnego Śląska podatki. Każdy Żyd musiał opłacać tzw. pogłówne, a ponadto na jej polecenie przeprowadzano zbiórki kosztowności, które następnie były przekazywane Niemcom ${ }^{34}$. Osoby niewypłacalne były „za karę” kierowane do obozów pracy, natomiast bogatsi mogli się „wykupić” od wysyłki i przedłużyć sobie wolność.

Merin nie uznawał kompromisów i niszczył ludzi, którzy nie chcieli mu ulec. To on doprowadził do odwołania Leona (Eliezera) Schönkera ze stanowiska przewodniczącego Rady Starszych w Oświęcimiu. Poróżniły ich przede wszystkim odmienne wizje polityki w stosunku do władz niemieckich. Podczas gdy Merin głosił wszem i wobec, że tylko polityka podporządkowania się może ocalić Żydów, Schönker odrzucał taką postawę i postulował „ocalenie przez emigrację”. Robił wszystko, co mógł, aby umożliwić wyjazd jak największej liczbie osób z obszaru rejencji katowickiej. Ponadto nie uznał zwierzchnictwa przewodniczącego CŻRS i nie

${ }^{31}$ Klein Mangersdorf - obecnie wieś Magnuszowiczki, położona w gminie Niemodlin w województwie opolskim.

${ }^{32}$ Gross Sarne - obecnie wieś Sarny Wielkie, położona w gminie Niemodlin w województwie opolskim.

${ }_{33}$ Maria Adlerflügel, Relacja, 1946, AŻIH, sygn. Relacje 301/2154, k. 6.

${ }^{34}$ Szternfinkiel, Zagłada Żydów z Sosnowca..., s. 19. 
zamierzał podporządkowywać mu gminy oświęcimskiej ${ }^{35}$. W lutym $1940 \mathrm{r}$. przestał być przywódcą społeczności żydowskiej w Oświęcimiu, a na tym stanowisku zastąpił go Józef Gross. Warto podkreślić, że przez bardzo krótki okres (niespełna miesiąc, w lipcu 1940 r.) na czele tamtejszej Rady Starszych stał Chaim Merin, oddelegowany jako zarządca komisaryczny ${ }^{36}$.

Henryk Schönker, syn Leona, na podstawie notatek i ustnych relacji ojca napisał książkę Dotknięcie anioła ${ }^{37}$, w której sporo uwagi poświęcił Merinowi. Pod koniec listopada 1939 r. Leon Schönker wraz z kilkoma zaufanymi współpracownikami udał się do Berlina, aby rozmawiać tam o możliwościach emigracyjnych. W stolicy Niemiec spotkał się m.in. z prof. Leo Baeckiem, przewodniczącym Zjednoczenia Żydów w Niemczech (Reichsvereinigung der Juden in Deutschland), który spytał go, czy zna sosnowieckiego Żyda o nazwisku Merin. Gdy Schönker odpowiedział, że nie słyszał o kimś takim, prof. Baeck ostrzegł go przed nim, twierdząc, że jest to zaufany człowiek Himmlera i Eichmanna ${ }^{38}$.

Przewodniczący oświęcimskiej Rady Starszych bardzo szybko przekonał się, że pogłoski na temat Merina nie były przesadzone. W styczniu 1940 r. na jego zaproszenie przyjechał do Sosnowca. Razem poszli na obiad do luksusowej restauracji. Podczas niezwykle wystawnego posiłku do lokalu przyszło kilku zdenerwowanych mężczyzn, którzy zbliżyli się do przewodniczącego CŻRS i zaczęli mu coś szeptać na ucho. Po tych słowach Merin opuścił restaurację, a Schönker z ciekawości poszedł za nim. To, co zobaczył na zewnątrz, zmroziło mu krew w żyłach. Po obu stronach ulicy z pochodniami w rękach stali żołnierze niemieccy, tworząc szpaler. Pomiędzy nimi szli inni żołnierze, prowadząc grupę pobitych, zmaltretowanych ludzi. Byli to członkowie Judenratu z Zawiercia, którzy nie zapłacili 30 tys. marek kontrybucji, jaką nałożyła na nich Centrala

${ }^{35}$ Leon Schönker (1903-1965) we wrześniu 1939 r. został przewodniczącym Żydowskiej Rady Starszych w Oświęcimiu, utworzył tam Centralne Biuro Emigracyjne. Na początku 1940 r. wraz z rodziną został zmuszony do ucieczki z miasta i podczas tułaczki wojennej przebywał w Krakowie, Wieliczce, w tarnowskim getcie i Bochni. Następnie cała rodzina Schönkerów trafiła do specjalnego obozu dla cudzoziemców w Bergen-Belsen, gdzie dzięki fałszywym dokumentom przebywali jako obywatele palestyńscy. Pięcioosobowa rodzina przeżyła wojnę i po jej zakończeniu wróciła do Oświęcimia. Zob. Artur Szyndler, Leon Schönker i jego plan emigracji Żydów z rejencji katowickiej z końca 1939 r., „Studia Judaica” 12 (2009), nr 1-2, s. 237-274; Henryk Schönker, Dotknięcie anioła, Warszawa 2011.

${ }^{36}$ Szyndler, Leon Schönker..., s. 251, przyp. 52.

${ }^{37}$ Książka ta ukazała się w trzech edycjach w latach 2005, 2006 i 2011. Ostatnia z nich została poszerzona o materiały źródłowe, w tym m.in. dokumenty znajdujące się w American Jewish Joint Distribution Committee Archives w Nowym Jorku.

${ }^{38}$ Schönker, Dotknięcie anioła..., s. 43. 
w Sosnowcu. Ponieważ nie dysponowali taką sumą, trafili do więzienia, gdzie ich torturowano. Po krótkiej rozmowie z Niemcami i dłuższych pertraktacjach z zawierciańskimi Żydami Merin zgodził się przyjąć od nich mniejszą kwotę, zastrzegając jednocześnie, że w najbliższej przyszłości muszą dopłacić brakującą część. Żołnierze poprowadzili więźniów dalej, a Merin - jakby nic się nie stało - wrócił do restauracji i kazał kelnerom przynosić następne potrawy i alkohol. Powołując się na wspomnienia ojca, Henryk Schönker podsumował tę sytuację w dwóch zdaniach: „Jego obojętność na cierpienie miała w sobie coś zwierzęcego. Ojciec mój miał wrażenie, że Merin w ogóle nie zdaje sobie sprawy, że ma do czynienia z żywymi ludźmi”’39.

Wracając do kwestii emigracji Żydów z obszaru rejencji katowickiej, należy zaznaczyć, że w pierwszych miesiącach wojny Merin sam był jej zwolennikiem. O ile jednak Schönker kierował się wyłącznie względami humanitarnymi i działał na tym polu bezinteresownie, o tyle Merin postępował zgoła odmiennie. Na początku lutego 1940 r. przeniósł oświęcimskie Biuro Emigracyjne do Sosnowca i tam weszło ono w skład Wydziału Emigracyjnego (Zentrale Emigrationsabteilung) działającego przy CŻRS od 1 lutego do końca kwietnia 1940 r. Biuro to zajmowało się handlem paszportami i certyfikatami, które krewni z zagranicy przysyłali swoim bliskim mieszkającym na obszarze Wschodniego Górnego Śląska. Niektórym ludziom w Palestynie, posiadającym znaczne zasoby gotówki i mającym odpowiednie układy z przedstawicielami władz angielskich, udawało się sprowadzić do tego kraju prześladowanych krewnych. Wysyłano wówczas do Polski przez jakiś neutralny kraj (najczęściej Szwajcarię) certyfikat lub dokument zapewniający prawo wjazdu (affidavit). Dokumenty te trafiały do Biura Emigracyjnego i po wymianie w nich fotografii sprzedawano je potrzebującym za duże pieniądze. Dostarczano tam również (oryginalne lub podrobione) paszporty różnych państw południowoamerykańskich. Ich cena także była bardzo wysoka i tylko nieliczni mogli sobie na to pozwolić ${ }^{40}$.

O tym, że Merin popierał emigrację, świadczą również słowa Emanuela Ringelbluma, który w kwietniu 1940 r. pisał o nim, że „dla sprawy emigracji gotów jest na wszystko i przed niczym się nie cofnie" ${ }^{41}$. Jednak historyk getta warszawskiego, który w swojej kronice niejednokrotnie wyrażał się o przewodniczącym CŻRS pochlebnie, twierdząc m.in., że to

\footnotetext{
39 Tamże, s. 61.

40 Tamże, s. 71.

${ }^{41}$ Cyt. za: Szyndler, Leon Schönker..., s. 252.
} 
„Król - gorące serce żydowskie”42, nie mógł wiedzieć, iż jego „bohater” traktował emigrację jako dochodowy proceder. Gdy bowiem z końcem kwietnia 1940 r. Wydział Emigracyjny Centrali został zlikwidowany, Merin nie miał poczucia winy, że zawiódł swoich pobratymców. Dobitnie świadczy o tym sprawozdanie z działalności CŻRS, w którym Fanny Czarna stwierdziła: „Uważaliśmy, że emigracja najlepszych jednostek jest zbrodnią wobec społeczeństwa. Nie żałowaliśmy, że tego nie było" ${ }^{43}$.

Poświęcenie najsłabszych dla ocalenia narodu - tak Merin argumentował swoje działania. Kreował się na nowego „Mesjasza”, który musi wiele poświęcić, aby zagwarantować Żydom przetrwanie. Często mówił o tym w teatralny sposób, a jego przemówienia były nasycone dramatycznymi metaforami, czego dowodzi następujący cytat:

Jestem w klatce, naprzeciwko wściekłego, głodnego lwa. Podsuwam mu ludzkie mięso, mięso moich braci i sióstr... Dlaczego? Robię to, ponieważ chcę utrzymać tego lwa w jego klatce, tak żeby nie mógł wyjść i zdeptać oraz pożreć nas wszystkich. [...] Niech osądzi mnie historia! ${ }^{44}$

Gdyby Merin działał w normalnych okolicznościach, historia nie miałaby problemów z osądzeniem go. Jednak wojna to dychotomia: życie-śmierć, walka-niewola, klęska-zwycięstwo. Przewodniczący CŻRS miał świadomość, że skazuje wielu ludzi na śmierć, ale wierzył, iż dzięki temu ocali innych. Szukał trzeciej drogi. O tym, że była to droga donikąd, przekonał się później.

\section{„Złoty okres" CŻRS}

Niewątpliwie jednak Mojżesz Merin należał do grona sprawnych administratorów, co przyznawały nawet niechętne mu osoby. Zwłaszcza lata 1940-1941 były dla niego sprzyjające. Wprawdzie na podległym mu terytorium obowiązywały ustawy antyżydowskie, ale skala represji wobec ludności żydowskiej pozostawała tam przez pewien czas na zdecydowanie niższym poziomie niż w pozostałych częściach Polski. Dzięki temu sytuacja bytowa Żydów zamieszkujących w gminach podlegających CŻRS była stabilniejsza w porównaniu z tym, co już wówczas miało miejsce w Generalnym

${ }^{42}$ Cyt. za: Namysło, Centrala Żydowskich Rad Starszych..., s. 48.

${ }^{43}$ Szyndler, Leon Schönker..., s. 253-254.

${ }^{44}$ Cyt. za: Mordecai Paldiel, Saving the Jews: Amazing Stories of Men and Women Who Defied the „Final Solution”, Rockville 2000, s. 129. 
Gubernatorstwie. Centrala rozwinęła szeroką działalność charytatywną, oświatową i kulturalną. Wiosną 1941 r. mogła pochwalić się licznymi sukcesami: w podległych jej gminach Żydzi nie głodowali, mieli pracę, a na ulicach właściwie nie spotykało się żebraków. Ludzie nie mieszkali w zamkniętych gettach (choć mogli poruszać się tylko po wyznaczonych ulicach) i mieli zapewniona podstawową opiekę medyczną, co przekładało się na stosunkowo niską śmiertelnośćc ${ }^{45}$. Sytuacja finansowa Centrali była korzystna głównie dzięki subwencjom otrzymywanym od Jointu (American Jewish Joint Distribution Committee). W Sosnowcu funkcjonowała filia tej organizacji, którą zarządzał Izaak Borenstein. Wspomagało ją również Zjednoczenie Żydów w Niemczech; w lutym 1941 r. przyznało ono CŻRS pożyczkę w wysokości 25 tys. marek. Stały dopływ gotówki spowodował, że Centrala mogła wspierać gminy żydowskie nawet spoza swojego regionu. Na początku 1941 r. pomoc finansową otrzymali np. Żydzi z Sieradza, Pabianic, Lutomierska i Widawy, a ludziom przebywającym w obozie w Kutnie wysłano lekarstwa i węgiel ${ }^{46}$.

Wszystkie te czynniki sprawiły, że grono zwolenników Merina się powiększało. Ludzie, którzy początkowo go krytykowali, zmieniali zdanie i przekonywali się do jego polityki, zwłaszcza do „koncepcji ocalenia przez pracę”. Jedną z takich osób był olkuski lekarz Marian Auerhahn, który przyznawał, że początkowo podchodził do działań zwierzchnika CŻRS $\mathrm{z}$ dużą rezerwą, ale zmienił zdanie po spotkaniu z nim:

Zrozumiałem, że wiele dobrego zrobił dla Żydów [...]. Wiedział, że Żydów czeka śmierć, ale liczył, że pewna garstka ocaleje. Poświęcał więc w akcjach, według niego najgorszych, chorych, starców, liczył się z tym, że najlepsi zostaną ${ }^{47}$.

Merin dbał o to, aby osiaggnięcia Centrali miały odpowiednią oprawę propagandową. Taką zyskała akcja przesiedlenia do Sosnowca, Będzina i Chrzanowa ponad 7 tys. Żydów oświęcimskich w kwietniu 1941 r. Centrala zapewniła wszystkim dach nad głową, a rodzinom, które odmówiłyby przyjęcia przesiedleńców, grożono karami. Ewa Neiger, jedna z mieszkanek Oświęcimia, zapamiętała, że akcja odbyła się podczas święta Pesach i trwała przeszło tydzień, ale była dobrze zorganizowana ${ }^{48}$. Wydarzenie to odbiło się szerokim echem poza granicami Wschodniego Górnego Śląska. Artykuł na

\footnotetext{
${ }^{45}$ Oxenhaendler, Ronen-Klinger, Z historii Żydów...

${ }^{46}$ Namysło, Centrala Żydowskich Rad Starszych..., s. 47.

47 Tamże, s. 48.

${ }^{48}$ Ewa Neiger, Relacja, 1946, AŻIH, sygn. Relacje 301/2442, k. 2-3.
} 
ten temat ukazał się w „Gazecie Żydowskiej” wydawanej w Krakowie pod nadzorem Wydziału Propagandy GG. Napisano w nim, że działania Centrali są modelowym przykładem współpracy z władzą niemiecką ${ }^{49}$. Fanny Czarna stwierdziła, że Żydzi oświęcimscy zostali uratowani od wywiezienia do Generalnego Gubernatorstwa, gdzie spotkałby ich straszny los, a sam przebieg akcji przesiedleńczej określiła jako majstersztyk ${ }^{50}$. Ci ludzie, których „ocalił” Merin, już w następnym roku wrócili do swojego miasta, jednak nie do domów, lecz do obozu koncentracyjnego Auschwitz-Birkenau.

Zanim jednak nastał najtragiczniejszy okres w dziejach ludności żydowskiej na omawianym terenie, Mojżesz Merin był jednym z najbardziej wpływowych przewodniczących rad żydowskich (o ile nie najbardziej wpływowym) w Polsce. Miał do dyspozycji samochód i kierowcę i mógł swobodnie się poruszać po terenach wcielonych do III Rzeszy i Generalnego Gubernatorstwa. Gościł w Warszawie, Krakowie, Łodzi (dwukrotnie), Opolu, Pradze i w Berlinie. Jego popularność rosła z dnia na dzień, a w odwiedzanych gettach był entuzjastycznie witany przez mieszkańców. Cytowany wcześniej Emanuel Ringelblum pisał o nim - przywołując słowa pewnej Żydówki - że był ,aniołem - Zbawicielem” ${ }^{51}$. Z kolei Baron Naftali, szofer Merina, wspominał, że do Sosnowca przyjeżdżali wysłannicy z różnych gett i prosili go o pomoc. W pamięci szczególnie utkwiła mu wizyta belgijskiego Żyda, który przybył z Łodzi i prosił Merina o objęcie kierownictwa w tamtejszej dzielnicy żydowskiej. Szef Centrali udał się do Łodzi i spotkał się z Mordechajem Chaimem Rumkowskim. Jego kierowca dokładnie zapamiętał ten pobyt i podkreślał, że mieszkańcy getta łódzkiego nie chcieli pozwolić im odjechać:

Za pierwszym razem, gdyśmy jechali do Łodzi, zajechaliśmy na placówkę, gdzie byli zbieracze szmat, a stamtąd pojechaliśmy do getta [...]. W getcie Merin udał się do Rumkowskiego. Konferowali około 30-45 minut, później pojechaliśmy w jednej taksówce z Merinem i Rumkowskim do szpitala żydowskiego. Rumkowski pokazywał nam urządzenia i czystość szpitala, później zjedli obiad, przebywaliśmy tam jeszcze pół godziny i zeszliśmy do taksówki. W podwórzu przy ulicy Łagownickiej koło naszej taksówki zebrał się kilkutysięczny tłum Żydów. Żydzi Ci nie pozwolili nam odjechać z getta i prosili Merina, ażeby im pomógł. Nie mogliśmy ruszyć z miejsca. Merin otworzył drzwiczki i powiedział po żydowsku „pomogę wam” ${ }^{2}$.

${ }^{49}$ Namysło, Centrala Żydowskich Rad Starszych..., s. 47.

${ }^{50}$ Tamże.

51 Tamże, s. 48.

${ }^{52}$ Baron Naftali, Relacja, 1946, AŻIH, sygn. Relacja 301/4301, k. 2-3. W taksówce poza szoferem i przewodniczącym CŻRS był jeszcze przedstawiciel Gestapo. 
W 1941 r. Merin gościł w Warszawie, gdzie również fetowano go jak króla. Oficjalnie został powitany w teatrze znajdującym się na terenie getta, a jeden z mieszkańców, Menachem Mendel, zaanonsował go słowami: „Nowy zbawca narodu żydowskiego!”53. Mimo tak gorącego powitania wizyta przewodniczącego CŻRS w Warszawie zakończyła się fiaskiem. Podczas spotkania z reprezentantami tamtejszego Judenratu próbował przekonać ich do skuteczności koncepcji „ocalenia przez pracę”, jednak przedstawione przezeń argumenty nie zrobiły wrażenia na Adamie Czerniakowie i jego współpracownikach. Warto odnotować, że w gronie zaufanych ludzi „prezesa” getta warszawskiego był Żyd z Zagłębia Dąbrowskiego, Jerzy Fürstenberg - syn bogatego będzińskiego przedsiębiorcy Szymona Fürstenberga ${ }^{54}$. Podczas pobytu w stolicy Merin mógł się spotkać ze swoim szwagrem, Abrahamem Gancwajchem, kierownikiem Urzędu do Walki z Lichwą i Spekulacją w Dzielnicy Żydowskiej, tzw. Trzynastki, będącego w istocie agenturą Gestapo.

\section{Konfrontacja z młodzieżą}

Liczne sukcesy Centrali nie oznaczały jednak, że mieszkańcy podlegających jej gmin nagle zapałali miłością do Merina. Jego plany nigdy nie zyskały akceptacji młodzieży żydowskiej działającej w ruchu oporu. Wywodziła się ona z kręgu Ha-Noar ha-Cijoni, Ha-Szomer ha-Cair, Droru i Gordonii, a opowiadała się za podejmowaniem radykalnych działań mających na celu zapobieżenie eksterminacji Żydów, nie wykluczając bezpośredniej konfrontacji z okupantem. O jej nastawieniu i przygotowywaniu się do walki zbrojnej świadczył fakt, iż już w pierwszych miesiącach wojny organizowała się w grupach samokształceniowych, nawiązała kontakty z Żydowską Organizacją Bojową w Warszawie (w 1942 r. do Zagłębia Dąbrowskiego przyjechali Mordechaj Anielewicz i Eliezer Geller, a emisariuszka Frumka Płotnicka stanęła na czele powstania, które wybuchło podczas akcji likwidacyjnej getta będzińskiego w sierpniu 1943 r.) i nie podporządkowywała się nakazom CŻRS. Albert Nirensztain, były pracownik Żydowskiego Instytutu Historycznego w Warszawie, w latach pięćdziesiątych XX w. opracował zarys dziejów żydowskiego ruchu oporu na terenie Zagłębia Dąbrowskiego. Wyniki jego badań pokazują, że do

53 Namysło, Centrala Żydowskich Rad Starszych..., s. 48.

${ }^{54}$ Marcin Urynowicz, Adam Czerniaków 1880-1942. Prezes getta warszawskiego, Warszawa 2009, s. 273-274. 
1943 r. to walka z Centralą była głównym celem działań młodzieży żydowskiej. W opublikowanym dopiero po kilkudziesięciu latach artykule $R u c h$ oporu Żydów w Zagtębiu Dąbrowskim pod okupacją hitlerowska napisał:

Dyktatorska prawie władza Merina, oparta nie tylko na terrorze stojącej za nim Gestapo, ale i na silnie rozbudowanej policji żydowskiej, zastępowała na Śląsku w bardzo dużej mierze samą władzę hitlerowską [...]. Fakt ten tłumaczy w pełni, dlaczego akcja oporu [...] skierowana była głównie przeciw centrali judenratowskiej jako instytucji, która stanowiła integralną część aparatu eksterminacyjnego Rzeszy hitlerowskiej ${ }^{55}$.

Merin był świadom tego, że postawa młodzieży żydowskiej może zrujnować jego plany związane z realizacją koncepcji „ocalenia przez pracę”. Bał się, że prędzej czy później wpłynie ona na pozostałych Żydów zamieszkujących Wschodni Górny Śląsk, co mogłoby wywołać bunt. Nie chcąc do tego dopuścić, zaczął udawać, że jest otwarty na współpracę z opozycjonistami. Pod koniec 1941 r. powołał przy CŻRS Wydział Młodzieżowy, na czele którego stanął Izrael Kożuch (posługiwał się również polskim imieniem Józef), lider Ha-Noar ha-Cijoni, który cieszył się wśród młodych ludzi ogromnym szacunkiem. Przyjmując ofertę Merina, wierzył, że będzie mógł realnie pomagać swoim rówieśnikom chociażby poprzez organizowanie kursów zawodowych czy prowadzenie akcji socjalnych. Tymczasem przewodniczący sosnowieckiego Judenratu, wykorzystując jego autorytet, chciał kontrolować działania młodzieży. Kożuch szybko się domyślił, jaką rolę miał odegrać, zerwał więc kontakty z Centralą i przystąpił do militarnej grupy młodzieży żydowskiej ${ }^{56}$.

Na początku 1942 r. przebywający w Sosnowcu Mordechaj Anielewicz spotkał z się Merinem i Fanny Czarną. Prawdopodobnie przywódca Żydowskiej Organizacji Bojowej próbował przekonać go do współpracy z młodzieżą i odstąpienia od posłusznego wykonywania poleceń zwierzchników niemieckich. Rozmowy te niczego nie zmieniły, ponieważ każda ze stron pozostała przy swoim stanowisku ${ }^{57}$.

${ }^{55}$ Nirensztain, Ruch oporu Żydów..., s. 592. Używając pojęcia „Śląsk”, autor miał na myśli Zagłębie Dąbrowskie.

${ }^{56}$ Ewa Starczewska, Anna Żelechowska, O godne życie i godna śmierć. Izrael Kożuch zapomniany bohater, [w:] Żydzi na Górnym Ślasku i w Zagłębiu Dąbrowskim. Historia, kultura, zagadnienia konserwatorskie, red. Dariusz Rozmus, Sławomir Witkowski, Kraków-Bytom 2011, s. 103.

${ }^{57}$ Fela Kac, Pozostało jedynie oznaczyć cenę, za która oddać trzeba było życie, „Ekspres Zagłębiowski” (1994), nr 7, s. 9. Zob. też Namysło, Centrala Żydowskich Rad Starszych..., s. 49. 
Nie mogąc zjednać sobie młodzieży żydowskiej, Merin szukał sojuszników gdzie indziej. Nowe grono zwolenników wzmocniłoby jego pozycję w konfrontacji z ruchem oporu. Mimo wcześniejszych urazów i sporów bardzo zależało mu na pozyskaniu ludzi związanych z rabinem Englardem, jednak popierające działania młodzieży środowisko ortodoksyjne nie zamierzało iść na współpracę z Judenratem. Podobną postawę przyjęli syjoniści (aczkolwiek nie jednomyślnie, bo część z nich gotowa była poprzeć politykę prowadzoną przez CŻRS), co było dla Merina bardzo przykre, gdyż sam utożsamiał się z ideologią syjonistyczną ${ }^{58}$.

Tymczasem młodzież żydowska dążyła do przekonania wszystkich do swoich racji. W Sosnowcu, Będzinie i innych miejscowościach zaczęła ukazywać się konspiracyjna gazetka pt. „Przełom”. Jej wydawanie zainicjował Mordechaj Anielewicz, który opublikował na jej łamach kilka artykułów. Fela Kac wspominała, że tytuł tego pisma, którego pomysłodawcą był również Anielewicz, to nie przypadek. „Przełom” miał pomóc $\mathrm{w}$ „,dokonaniu przełomu w dotychczasowym nastawieniu ludności żydowskiej i zorganizowaniu się celem stawienia oporu" 59 . Zawarte w nim teksty przedstawiały Judenrat jako narzędzie w rękach Gestapo i nawoływały do walki z nim tak jak z Niemcami. Poza tą gazetką konspiratorzy żydowscy kolportowali również ulotki zawierające podobne jak w piśmie treści. Zostawiali je w miejscach publicznych, „szopach”, a nawet przed siedzibą CŻRS ${ }^{60}$.

Początkowo działacze ruchu oporu organizowali oficjalne, a w późniejszym czasie także nielegalne przerzuty młodych Żydów na Słowację, a stamtąd przez Turcję do Palestyny lub wysyłali ich - na aryjskich papierach - na roboty w głąb Rzeszy. Starali się także o wyrobienie paszportów krajów niebędących w stanie wojny z Niemcami (głównie państw południowoamerykańskich), gdyż uzyskanie statusu „obcokrajowca” zapewniało umieszczenie w tzw. obozie Internierungslager, a potem wyjazd do państwa neutralnego. Potwierdzenie obywatelstwa nowego kraju otrzymywano za pośrednictwem przedstawicieli partii żydowskich przebywających w Szwajcarii ${ }^{61}$.

58 Aleksandra Namysło, Wptyw kierownictwa Centrali Żydowskich Rad Starszych Wschodniego Górnego Ślaska na postawy i zachowania Żydów wobec rzeczywistości okupacyjnej, [w:] Zagłada Żydów na polskich terenach wcielonych do Rzeszy, red. Aleksandra Namysło, Warszawa 2008, s. 177.

${ }_{59}$ Nirensztain, Ruch oporu Żydów..., s. 588.

${ }^{60} \mathrm{Kac}$, Pozostało jedynie oznaczyć cenę..., s. 9.

${ }^{61}$ Namysło, Postawy mieszkańców rejencji katowickiej..., s. 779-780. 
Merin bacznie obserwował poczynania młodzieży żydowskiej i - wykorzystując milicję - inwigilował wrogie mu otoczenie. W maju 1942 r. żydowscy konspiratorzy licznie uczestniczyli w pogrzebie jednego z członków ruchu oporu, Kalmana Tencera. Po zakończeniu uroczystości pogrzebowych na cmentarzu pozostało kilka osób. Funkcjonariusze żydowscy, bacznie obserwujący przebieg pogrzebu, zatrzymali przed wejściem na cmentarz 11 osób, które zostały doprowadzone do siedziby Centrali. Nie wyciągnięto jednak wobec nich poważniejszych konsekwencji; po wylegitymowaniu i zanotowaniu nazwisk członkowie ruchu oporu zostali wypuszczeni ${ }^{2}$. Akcja ta miała na celu zastraszenie młodzieży, jednak nie odniosła zaplanowanego skutku.

Zarządzanej przez Merina Centrali Żydowskich Rad Starszych na Wschodnim Górnym Śląsku palił się grunt pod nogami. Od połowy $1942 \mathrm{r}$. zaufanie do tej instytucji zaczęło spadać, mimo że sytuacja bytowa mieszkańców żydowskich tego regionu pozostawała nadal względnie korzystna. Momentami próby dla przewodniczącego CŻRS były masowe wysiedlenia ludności żydowskiej na podlegającym mu obszarze w maju i sierpniu tego roku. Merin zdawał sobie sprawę z tego, że prowadzona przezeń polityka staje się coraz mniej skuteczna i że Niemcy nie pozostawiają mu już takiej swobody działania, jaką miał parę miesięcy wcześniej. Jeszcze pod koniec 1941 r. podczas narady kierowników wydziałów CŻRS mówił: „Sytuacja polityczna bardzo poważna. Nieprzychylne nastawienie władz do nas. [...] Jeżeli nie będą mieć do nas zaufania, przestaniemy istnieć jako partner. [...] Musimy utrzymać autorytet Centrali i gmin"63.

\section{Wysiedlenia}

Kilka tygodni później na Wschodnim Górnym Śląsku zaczęto realizować tzw. ostateczne rozwiązanie kwestii żydowskiej (Endlösung). Już na początku 1942 r. wysłano stamtąd do Auschwitz pierwszy transport składający się z kilkuset osób. W kwietniu tego roku Judenrat na polecenie Gestapo wydał odezwę, w której apelował do mieszkańców tego terenu o przygotowanie walizek, koców i łóżek polowych, ponieważ część ludności miała zostać przesiedlona. Wśród osób mających opuścić Sosnowiec krążyła pogłoska, że pojadą do Theresienstadt (czeski Terezin), jednak

\footnotetext{
62 Nirensztain, Ruch oporu Żydów..., s. 594.

${ }^{63}$ Cyt. za: Namysło, Centrala Żydowskich Rad Starszych..., s. 50.
} 
miejsce ich przeznaczenia znajdowało się kilkadziesiąt kilometrów dalej, w Oświęcimiu. Jednocześnie pracownicy Centrali sporządzili listę pracujących, bezrobotnych i „elementów bezużytecznych”, za które uznano głównie dzieci i starców ${ }^{64}$. Natan Eliasz Szternfinkiel, autor książki Zagłada Żydów z Sosnowca (wydanej już w 1946 r.) pisał, że powyższe działania stanowily wstępne przygotowania do eksterminacji tamtejszych Żydów ${ }^{65}$. Tak faktycznie było.

Systematyczna zagłada Żydów z Sosnowca i innych miejscowości znajdujących się pod zwierzchnictwem CŻRS rozpoczęła się w maju 1942 r. Dwunastego dnia tego miesiąca odbyła się masowa akcja wysiedleńcza, w wyniku której kilka tysięcy osób wysłano do obozu Auschwitz-Birkenau (3600 z Sosnowca, 3200 z Będzina i 2000 z Zawiercia) ${ }^{66}$. Samuel Brechner, jeden z nielicznych ocalałych żydowskich mieszkańców Sosnowca zapamiętał, że CŻRS niezwykle starannie przygotowała się do przeprowadzenia tej akcji, a po jej zakończeniu Merin i jego współpracownicy urządzili pijatykę:

Z początkiem maja 1942 roku Judenrat na rozkaz Gestapo wysłał ok. 5000 wezwań do niepracujących, starych, kobiet i dzieci, nakazując im stawić się 10 maja o godz. 10-tej rano w budynku byłej szkoły na Dęblińskiej 13 z bagażem do $10 \mathrm{~kg}$, celem przesiedlenia ich. [...] Pewna grupa osób, członków różnych żydowskich partii politycznych, jak np. Bund, Ha-Szomer ha-Cair, Poalej-Syjon lewica, komuniści, w odpowiedzi na tę akcję Judenratu wydają potajemną odezwę do ludności żydowskiej w języku polskim. [...] W odezwie tej nawołują masy żydowskie do niestawienia się we wskazanym przez Judenrat miejscu i terminie. Akcja oporu udała się. 10 maja 1942 roku stawiły się na punkt aż 3 osoby. Wskutek tego w samym dniu 10 maja gestapo zmobilizowało większe siły i w asyście Judenratu otoczyli w nocy przy świetle reflektorów domy: Modrzejowską 23, Targową 11 i Targową 2, zabrali stamtąd całą ludność żydowską i zgromadzili ją w kinie Rialto na ulicy Warszawskiej 20. [...] 11 maja 1942 roku o 11-godz. przed południem, gestapo otacza ulicę Targową i zabiera stamtąd wszystkich bez wyjątku Żydów, tak pracujących, jak i nie pracujących i ładuje ich do wagonów. Nazajutrz wszyscy zostają wysłani na zagładę do Oświęcimia [...]. Tam wszyscy zginęli w komorach gazowych. W tym transporcie znajdował się także rabin z Sosnowca Englard ze swoją rodziną. [...] Judenrat $\mathrm{z}$ Merinem na czele nie przejmuje się tym wydarzeniem i urządzają sobie hulanki, gdzie szaleją całą noc ${ }^{67}$.

Relacja Samuela Brechnera dowodzi, że wiosną 1942 r. większym posłuchem wśród mieszkańców gmin żydowskich cieszyli się członkowie

\footnotetext{
${ }^{64}$ Szternfinkiel, Zagłada Żydów z Sosnowca ..., s. 32-33.

${ }_{65}$ Tamże, s. 33.

${ }^{66}$ Namysło, Postawy mieszkańców rejencji katowickiej..., s. 781.

${ }^{67}$ Samuel Brechner, Relacja, 1946, AŻIH, sygn. Relacja 301/1564, k. 13-15.
} 
ruchu oporu aniżeli Merin. To zachęcało konspiratorów do prowadzenia działań na szerszą skalę. W tym czasie terenem ich aktywności stały się zakłady pracy. W szopie produkującym obuwie wojskowe dla Niemców walczących na froncie wschodnim do każdego buta wkładali ulotkę wzywającą żołnierzy do poddania się i do tego, aby ,nie walczyli przeciwko tym, którzy chcą wyzwolić ludzkość z niemiecko-hitlerowskiego ucisku"68.

Anna Lerchenfeld z Będzina już po wojnie mówiła, że „począwszy od pierwszego wysiedlenia nie miało się ani jednej nocy spokojnej”" ${ }^{\prime}$. W czerwcu tego roku odbyły się następne akcje, natomiast w lipcu zlikwidowano mniejsze skupiska ludności żydowskiej w Olkuszu, Kłobucku, Zatorze, Ząbkowicach, Jaworznie, Trzebini, Grodźcu i Blachowni ${ }^{70}$. Od maja do lipca z terenów podlegających CŻRS wysiedlono ok. 15 tys. Żydów. Każdą akcję nadzorował Merin w asyście Hansa Dreiera i Friedricha Kuczynskiego, jednego z zaufanych współpracowników Albrechta Schmelta. Jednak najgorsze miało dopiero nadejść.

Największa akcja wysiedleńcza na omawianym obszarze odbyła się 12 sierpnia 1942 r. Do KL Auschwitz wywieziono ponad 20 tys. Żydów. Zorganizowano ją rzekomo w celu ostemplowania dowodów osobistych, aby zarejestrować osoby zdolne do pracy. Centrala zwoływała w terenie wiece, podczas których Merin i Czarna wygłaszali przemówienia zachęcające zebranych do stawienia się na punkty zborne. Rozlepiano też afisze z informacjami, jak należy się zachować i co trzeba ze sobą zabrać, np.:

Żydzi, włóżcie dobre, świąteczne ubrania. Weseli i chętni podążcie na punkt. Niech nie zostanie w domu ani jeden Żyd, bo ten, który zostanie w domu, nie będzie mógł nadal mieszkać $\mathrm{w}$ Zagłębiu ${ }^{71}$.

W tym dniu do rejestracji zgłosiło się blisko 50 tys. Żydów. Już o świcie wyruszyli na punkty zborne, które zorganizowano przeważnie na boiskach sportowych. Wyjątkowo pozwolono im przejść przez „Judenbannstraßen”, czyli ulice, po których na co dzień nie mogli się poruszać. Natan Eliasz Szternfinkiel pisał o tym dniu, że była to historyczna „czarna środa”’2. Przez cały dzień ludzie stali stłoczeni na punktach zbornych w upale, a potem w deszczu. Nie dostali nic do jedzenia ani do picia. Dopiero po południu nastąpiła „rejestracja”, w której wyniku zostali podzieleni na kilka grup.

${ }^{68}$ Cyt. za: Nirensztain, Ruch oporu Żydów..., s. 595.

${ }^{69}$ Zob. Anna Lerchenfeld, Relacja, [w:] Strzelecki, Zagłada Żydów..., s. 697.

${ }^{70}$ Namysło, Postawy mieszkańców rejencji katowickiej..., s. 781.

${ }^{71}$ Nirensztain, Ruch oporu Żydów..., s. 591.

72 Szternfinkiel, Zagłada Żydów z Sosnowca..., s. 37. 
Część zgromadzonych mogła wrócić do domów, część została skierowana na roboty przymusowe, a ostatnią grupe „ewakuowano”, co w rzeczywistości oznaczało śmierć w komorach gazowych Auschwitz-Birkenau ${ }^{73}$.

\section{Zamach na Merina}

Po 12 sierpnia zradykalizowały się działania młodzieży zaangażowanej w konspirację. Policja żydowska na polecenie Merina śledziła niemal każdy jej krok, ale - jak podkreślał Nirensztain - „popularność grup oporu w żydowskim społeczeństwie była znaczna. Świadczy o tym stosunkowa łatwość, z jaką grupa ta ukrywała się przed poszukiwaniami policji" ${ }^{74}$. Sierpniowe wysiedlenia i poparcie rodaków skutkowały decyzją o zamordowaniu Merina. Zamachu podjął się Cwi Duński, członek Ha-Szomer ha-Cair i jeden z liderów Żydowskiej Organizacji Bojowej w Zagłębiu Dąbrowskim, wraz z dwoma towarzyszami. Zaopatrzeni w kwas solny i robocze żelazne rękawice, czekali na przewodniczącego CŻRS w bramie zamieszkiwanej przezeń kamienicy. Gdy ten nadszedł po kilku godzinach, otoczony świtą 20 policjantów, niedoszli zabójcy zrezygnowali z planu, niezauważalnie opuścili posterunek i nie podejmowali kolejnych prób zabicia Merina ${ }^{75}$. Duński za próbę zamachu zapłacił życiem. Został aresztowany w lutym 1943 r. i przetrzymywany w sosnowieckim więzieniu, gdzie był przesłuchiwany i torturowany, a następnie przewodniczący Judenratu osobiście przekazał go Gestapo w Katowicach. Tam został zamordowany ${ }^{76}$.

Walka konspiratorów z CŻRS zaostrzała się z dnia na dzień. Ruch oporu zaczął kolportować ulotki, w których nawoływał mieszkańców do gromadzenia broni i wystąpienia przeciwko Judenratowi. Odezwy te były opatrzone kryptonimem „Czarna Ręka”. W odpowiedzi Merin zdelegalizował żydowskie organizacje młodzieżowe, które niedługo potem rozwiązano $^{77}$. Przeciwko Merinowi występowali także pracownicy Centrali. Jako

${ }^{3}$ Opis rejestracji na punktach zbornych znajduje się m.in. w pamiętniku 14-letniej Żydówki z Będzina, Rutki Laskier, która zginęła w Auschwitz: „O 3-ej [...] rozpoczęła się segregacja. 1 to powrót, 1a to roboty, co jest stokroć gorsze od wysiedlenia, 2 »do przejrzenia «, a 3 to »wysiedlenie «, czyli śmierć”. Rutka Laskier, Pamiętnik, red. Adam Szydłowski, Będzin 2008, s. 59. Pisał o niej również Szternfinkiel, ale zaznaczał, że: „zakwalifikowanie do tej lub innej grupy zależało w pierwszym rzędzie od humoru gestapowców, od stopnia ich trzeźwości [...] i od ich zachcianek”. Szternfinikiel, Zagłada Żydów z Sosnowca ..., s. 38.

${ }^{74}$ Nirensztain, Ruch oporu Żydów..., s. 595.

75 Tamże, s. 596.

${ }^{76}$ Szternfinkiel, Zagłada Żydów z Sosnowca ..., s. 44.

77 Namysło, Centrala Żydowskich Rad Starszych..., s. 51. 
pierwszy z pracy w niej zrezygnował Majer Brzeski, kierownik Wydziału Pracy Przymusowej. Po nim z CŻRS odszedł Paweł Wiederman, który pracował w Wydziale Przewarstwawiania ${ }^{78}$. To dało asumpt do coraz częstszych otwartych protestów innych ludzi, którzy nie zważali na grożące im konsekwencje. Pewnego dnia kobiety żydowskie zorganizowały pod siedzibą Judenratu demonstrację. Domagały się powrotu mężów i synów z obozów pracy przymusowej. Wykrzykiwały obraźliwe hasła pod adresem CŻRS i wybiły kilka szyb w oknach jej siedziby. Rozeszły się dopiero po zdecydowanej interwencji milicji żydowskiej ${ }^{79}$.

\section{Zamknięte getta}

Wiosna i lato 1942 r. przyniosły więc ogromny spadek zaufania do Centrali, ale już jesienią tego roku pozycja Merina ponownie wzrosła. Wpłynął na to fakt zaprzestania wysiedleń. Mieszkańcy podlegających mu gmin żydowskich uwierzyli, że najgorsze minęło i teraz ponownie zapanuje spokój. Nadzieje te jednak okazały się płonne. W tym czasie na terenie Wschodniego Górnego Śląska zostały podjęte działania w zakresie koncentracji ludności żydowskiej w określonych częściach miast. Do tego momentu na tym obszarze nie było zamkniętych gett, aczkolwiek Żydzi mogli się poruszać tylko po określonych ulicach i mieli zakaz przebywania w centrum miast. Jednak po akcjach wysiedleńczych i skierowaniu dziesiątków tysięcy osób do obozów pracy przymusowej gettoizacja stała się kolejnym etapem do zaplanowanej zagłady wszystkich Żydów.

W omawianym rejonie pierwsze przesiedlenia do zamkniętych dzielnic żydowskich rozpoczęły się na początku października 1942 r. Najpierw zostali wyizolowani mieszkańcy Będzina, Sosnowca i Dąbrowy Górniczej. Dla Żydów z Sosnowca wydzielony został teren poza centrum, w polskich dzielnicach robotniczych: Starym Sosnowcu i Środuli (z czasem getto na Starym Sosnowcu zostało zlikwidowane, gdyż znajdowały się w nim osoby chore i niezdolne do pracy, które wywieziono do Auschwitz). Natomiast do graniczących z nimi dzielnic - Kamionki i Małej Środuli - zamierzano przenieść Żydów będzińskich. W tych dwóch miastach akcje przesiedleńcze zakończono w marcu 1943 r., a getta ostatecznie zamknięto w maju. Przebywało w nich wówczas ok. 30 tys. osób (tylko getto w Sosnowcu liczyło

\footnotetext{
78 Tamże.

${ }^{79}$ Brechner, Relacja..., k. 11.
} 
ok. 20 tys. mieszkańców) ${ }^{80}$. Przeniesiono do nich również najważniejsze szopy, tak aby zachować ciaggłość produkcji wojennej.

W 1943 r. zamknięte dzielnice żydowskie powstały również w Dąbrowie Górniczej (na początku roku), Strzemieszycach (w marcu) oraz w Czeladzi (najpóźniej w kwietniu). Jednak funkcjonowały one bardzo krótko, gdyż już w lipcu tego roku zostały zlikwidowane. Część ich mieszkańców przeniesiono do gett w Będzinie i Sosnowcu, natomiast pozostałych wysłano na zagładę.

Idea utworzenia zamkniętych dzielnic żydowskich spotkała się z aprobatą Mojżesza Merina, a według Pawła Wiedermana - był on jednym z jej twórców ${ }^{81}$. Nawet świadomość, że to na Centralę spadnie obowiązek pokrycia wszystkich kosztów związanych nie tylko z przesiedleniem ludności żydowskiej, lecz także z przekwaterowaniem Polaków do ich mieszkań, nie była w stanie ugasić jego entuzjazmu.

Aleksandra Namysło, historyk z katowickiego oddziału Instytutu Pamięci Narodowej, która w swoich badaniach wiele uwagi poświęciła działalności Centrali Żydowskich Rad Starszych na Wschodnim Górnym Śląsku, stwierdziła, że Merin popierał utworzenie gett z dwóch powodów. Po pierwsze, zgromadzenie Żydów poza centrami miast miało zapewnić im względny spokój poprzez „zejście z oczu” władzom niemieckim, a to mogło zagwarantować, przynajmniej na jakiś czas, zmniejszenie skali represji. Po drugie - co chyba istotniejsze - Żydzi zostaliby całkowicie odseparowani od ludności „aryjskiej”, w związku z czym utrzymywanie wzajemnych kontaktów stało się praktycznie niemożliwe ${ }^{82}$. Merin potępiał te relacje nawet w sytuacjach, w których mogły one uratować Żydom życie.

Mordecai Paldiel w książce Saving the Jews: Amazing Stories of Men and Women Who Defied the „Final Solution” opublikował relację Henrietty (Kitii) Altman, mieszkanki Będzina, która w czasie II wojny światowej pracowała w szopie należącym do Alfreda Rossnera. Niemiecki Treuhänder ratował swoich pracowników, za co w 1995 r. został odznaczony medalem „Sprawiedliwy wśród Narodów Świata” przyznawanym przez Instytut Yad Vashem w Jerozolimie. Kitia Altman wspominała, że Merin torpedował działania Rossnera:

W swojej gorliwości, aby zadowolić Panów z SS, Merin często informował ich o praktykach stosowanych w fabrykach Rossnera, które miały być sabotowaniem

${ }^{80}$ Namysło, Postawy mieszkańców rejencji katowickiej..., s. 783.

${ }^{81}$ Namysło, Centrala Żydowskich Rad Starszych..., s. 52, przyp. 80.

82 Tamże, s. 52. 
wysiłków Merina w wypełnieniu kontyngentu Żydów przeznaczonych do deportacji. W zakładzie, który należał do SS, zarządzanym przez osobę nie związaną z SS, jedynym ratunkiem dla Żydów było uznanie ich za pracowników niezbędnych z punktu widzenia niemieckich potrzeb wojennych. Tymczasem SS żądało od Judenratu dostaw Żydów, a ten nie mógł ich zapewnić, ponieważ chroniła ich praca u Rossnera ${ }^{83}$.

20 grudnia 1942 r. w 350 numerze gazety „Pariser Zeitung” został opublikowany wywiad z Merinem, w którym nakreślił on idealny obraz życia w getcie. Z przewodniczącym Centrali spotkał się słowacki dziennikarz Fritz Fial. Rozmowa ukazała się w artykule, którego tytuł w polskim przekładzie brzmi: „W żydowskim obozie na Wschodzie. Spotkanie z paryskimi Żydami - lekcja poglądowa wobec rooseveltowskiej propagandy o rzekomych okrucieństwach”. Przewodniczący CŻRS, oprowadzając gościa po Będzinie i Sosnowcu, mówił:

Na moim terenie mieszka teraz ok. 70 tys. Żydów. Zostali oni wraz ze swoimi rodzinami zakwaterowani w obu miastach i choć domy należą do państwa, mieszkają tu całkiem wolni i cieszą się prywatnością [...]. Ludność żydowska jest w wystarczającym stopniu zaopatrywana w artykuły spożywcze, które tak, jak i inne przedmioty można swobodnie kupić w żydowskich sklepach [...]; za pracę Żydzi otrzymują stosowną zapłatę, którą dowolnie mogą gospodarować. [...] Jak dotąd nie odnotowaliśmy ani epidemii chorób zakaźnych, ani innych incydentów ${ }^{84}$.

Słowacki dziennikarz był pod wielkim wrażeniem Merina. Świadczy o tym jego komentarz, który ukazał się pod tekstem wywiadu. Podkreślił w nim, że Żydzi w wizytowanych przez niego miastach mieli pod dostatkiem żywności, w zakładach, w których pracowali, panowała czystość, a czas wolny spędzali w kawiarniach, gdzie czytali gazety.

Rzeczywistość, jak wiadomo, wyglądała jednak zupełnie inaczej. Żydzi w gettach cierpieli głód, a ich wyniszczone ciała trawiły liczne choroby. W zapewnienia Merina, że powstaną tam sklepy spożywcze i służące Żydom inne instytucje użytku publicznego, nikt już nie wierzył. Ponadto niebawem zostały wznowione wysiedlenia. Zamknięci w gettach ludzie coraz częściej bojkotowali pracę w szopach, nie reagowali na apele władz dotyczące zbiórek kosztowności na okup dla Niemców i nielegalnie utrzymywali listowny kontakt z zagranicą. Nie liczyli się ze zdaniem

${ }^{83}$ Paldiel, Saving the Jews..., s. 129-130. Do Alfreda Rossnera należało kilka szopów, które produkowały przede wszystkim mundury dla żołnierzy Wehrmachtu i obuwie wojskowe. Niemiec został Treuhänderem, mimo że nigdy nie należał do NSDAP.

84 Za: Namysło, Wplyw kierownictwa Centrali..., s. 178. 
Centrali, której pracownicy utracili uprzywilejowaną pozycję i znaleźli się w takiej samej sytuacji, jak miliony innych prześladowanych Żydów w całej Europie.

\section{Droga ku Auschwitz}

W dniach 20, 24 i 25 czerwca 1943 r. z gett w Sosnowcu-Środuli i Będzinie-Kamionce wywieziono do KL Auschwitz co najmniej 4145 Żydów, z których większość niezwłocznie po przyjeździe zamordowano w komorach gazowych ${ }^{85}$. W jednym z tych transportów znaleźli się najprawdopodobniej Mojżesz Merin, jego brat Chaim i inni czołowi przedstawiciele CŻRS. W powojennych relacjach wspominali o tym ocaleni z Zagłębia Dąbrowskiego. Helena Żmigród z Będzina zeznawała, że pod koniec czerwca „Mońka Merina już nie było, Centrali Żydowskiej już nie było, a Gestapo z innymi przedstawicielami nie liczyło się" ${ }^{\text {" }}$. Z kolei Paweł Wiederman twierdził, że Merin i wywiezione razem z nim osoby (Fanny Czarna, Aron Lewensztajn i Izaak Borenstein) zostały zamordowane w Auschwitz 6 lipca 1943 r. ${ }^{87}$, natomiast Danuta Czech w Kalendarzu wydarzeń w KL Auschwitz pod datą 20 czerwca 1943 r. odnotowała fakt, że wśród 45 Żydów przybyłych tego dnia do obozu najprawdopodobniej znajdowali się członkowie CŻRS z Sosnowca ${ }^{88}$. Śmierci Merina w tym obozie jednak nigdy oficjalnie nie potwierdzono.

Po wywiezieniu kierownictwa Centrala Żydowskich Rad Starszych na Wschodnim Górnym Śląsku funkcjonowała jeszcze około miesiąca. Na jej czele stanął Wolf Śmietana, nie miał on jednak takiej charyzmy i zdolności przywódczych, jak Merin. Ponadto nie podlegała mu kadra wykwalifikowanych urzędników, a mieszkańcy nie darzyli go sympatią. Działalność Centrali zakończyła się wraz z deportacją niemalże całej ludności z dwóch największych gett na podlegającym jej obszarze. Akcja likwidacyjna rozpoczęła się 1 sierpnia $1943 \mathrm{r}$. i w Sosnowcu trwała 16 dni. Na miejscu pozostało jedynie kilkaset osób, którym nakazano uporządkować teren getta i dokończyć pracę w szopie należącym do Rudolfa Brauna.

Getto będzińskie opustoszało w ciągu ośmiu dni. W tym czasie doszło do walk, gdyż członkowie Żydowskiej Organizacji Bojowej wzniecili powstanie.

\footnotetext{
${ }^{85}$ Strzelecki, Zagłada Żydów..., s. 159.

${ }^{86}$ Helena Żmigród, Relacja, 1945, AŻIH, sygn. Relacje 301/526, k. 6.

${ }^{87}$ Strzelecki, Zagłada Żydów..., s. 172.

${ }^{88}$ Danuta Czech, Kalendarz wydarzeń w KL Auschwitz, Oświęcim 1992, s. 446-447.
} 
Nierówny bój z Niemcami trwał trzy dni. Większość bojowników zginęła, w tym przysłana z Warszawy Frumka Płotnicka. Z Będzina wysiedlono wówczas ponad 12 tys. Żydów. Najpóźniej, bo 26 sierpnia, unicestwiono liczącą 2500 osób społeczność żydowską Zawiercia. Łącznie w tym okresie w transportach do KL Auschwitz znalazło się 30 tys. ludzi ${ }^{89}$, a ok. 3500 osób wysłano tam w następnych miesiącach. W sumie od maja 1942 r. do lipca 1944 r. wywieziono na śmierć w obozach koncentracyjnych i zabito podczas akcji deportacyjnych ok. 65 tys. Żydów z Zagłębia Dąbrowskiego ${ }^{90}$.

\section{Podsumowanie}

Mojżesz Merin to postać budząca wiele kontrowersji. Kim był: zbawcą, kolaborantem czy zagubionym człowiekiem, którego przerosła rzeczywistość? Udzielenie jednoznacznej odpowiedzi na to pytanie jest bardzo ryzykowne. W relacjach Żydów, którzy w czasie II wojny światowej podlegali jurysdykcji Centrali Żydowskich Rad Starszych na Wschodnim Górnym Śląsku, odnajdujemy sprzeczne opinie na jego temat. Jednym jawił się jako charyzmatyczny przywódca i sprawny administrator, innym - jako kolaborant i niemiecka marionetka, która dla zapewnienia bezpieczeństwa sobie i swoim najbliższym była gotowa poświęcić tysiące rodaków. Ten skrajnie zróżnicowany wielogłos na temat Merina był zapewne związany z różnorodnością postaw wywołanych ciężką sytuacją wojenno-okupacyjną, zachwianiem norm i zasad moralnych oraz ciągłym zagrożeniem życia. Ludzie żyjący w tej nienaturalnej rzeczywistości, osoby prywatne, a tym bardziej funkcjonariusze administracji żydowskiej, zostali zmuszeni do podejmowania trudnych i szybkich decyzji, których konsekwencje mogły doprowadzić do nagłej śmierci lub życia w niezgodzie ze swoim sumieniem. Pamiętając o tym, spróbujmy przeanalizować postępowanie Merina podczas okupacji niemieckiej.

Nie ulega wątpliwości, że był on zwolennikiem wszechstronnej i spolegliwej współpracy z okupantem. Działania, które podjął na kierowniczym stanowisku, szybko też ujawniły jego cechy charakterologiczne. Tłumił w zarodku każdy przejaw niesubordynacji czy buntu i nakazywał sumienną pracę na rzecz niemieckiej gospodarki wojennej. Nie da się zaprzeczyć, że wielu krytykowało koncepcję „ocalenia przez pracę”, jednak to dzięki niej

\footnotetext{
${ }^{89}$ Namysło, Postawy mieszkańców rejencji katowickiej..., s. 787-788.

${ }^{90}$ Strzelecki, Zagłada Żydów..., s. 204.
} 
Merin zapewnił w pierwszych latach wojny Żydom z terenów Wschodniego Górnego Śląska nieporównywalnie lepsze warunki egzystencji od tych, w których znaleźli się ich rodacy mieszkający na obszarze Generalnego Gubernatorstwa czy Okręgu Kraju Warty. Stworzył również rozbudowany system polityki socjalnej, dzięki czemu do połowy 1942 r. w podlegających mu gminach żydowskich nie występowało zjawisko powszechnego głodu. Przesadą byłoby jednak przypisywanie tych wszystkich sukcesów tylko i wyłącznie jemu. Pomogła mu nie do końca sprecyzowana polityka władz niemieckich wobec ludności żydowskiej zamieszkującej ten obszar oraz chęć jego gospodarczego wyeksploatowania, do czego niezbędna była masa robotników przymusowych.

$\mathrm{Z}$ jednej strony wydawało się, że Merin naprawdę troszczył się o losy mieszkańców, z drugiej jednak nie akceptował żadnej formy sprzeciwu, co doprowadziło do tego, że był skonfliktowany z wieloma grupami społecznymi. Przeżywał wzloty i upadki, ale niezależnie od sytuacji, w jakiej się znajdował, konsekwentnie, do samego końca, realizował swoją politykę. Trudno określić, jakie motywy nim kierowały. Czy tak bardzo wierzył w forsowane założenia, że stracił zdolność racjonalnego myślenia i nie zdawał sobie sprawy z grozy sytuacji? Czy kierowała nim jedynie głęboka troska o współobywateli? A może po prostu nie potrafił i nie chciał przyznać się do porażki?

Wydaje się prawdopodobne, iż władza w pewnym momencie uderzyła przewodniczącemu CŻRS do głowy. Poczuł się na tyle potężny, że nie liczył się z niczyim zdaniem, z wyjątkiem niemieckich zwierzchników. Brak otwarcia na dyskusję i odmienne poglądy skutkowały tym, że nawet nie poszukiwał innych możliwości ocalenia jak największej liczby Żydów. Oczywiście można się zastanawiać, co by było, gdyby Merin prowadził inną politykę, gdyby był bardziej skłonny do kompromisów. Jednak takie zastanawianie się zarówno dzisiaj, jak i kilkadziesiąt lat wcześniej jest i było tylko teoretyczne. W styczniu 1942 r. zapadła bowiem nieodwołalna decyzja o „ostatecznym rozwiązaniu kwestii żydowskiej”. Od tego momentu nie było mowy o jakiejkolwiek racjonalnej polityce wobec Żydów. Czekała ich już tylko Zagłada. 


\section{Bibliografia}

\section{1. Źródła archiwalne}

Archiwum Żydowskiego Instytutu Historycznego

Relacje:

Adlerflügel Maria, 1946, Relacja, sygn. Relacje 301/2154.

Brechner Samuel, Relacja, 1946, sygn. Relacja 301/1564.

Fischer Dawid, Relacja, b.d., sygn. Relacje 301/1335.

Naftali Baron, Relacja, 1946, sygn. Relacje 301/4301.

Neiger Ewa, Relacja, 1946, sygn. Relacje 301/2442.

Sender Jakub, Relacja, b.d., sygn. Relacje 301/1225.

Żmigród Helena, Relacja, 1945, sygn. Relacje 301/526.

Wstęp do inwentarza zespołu akt Vorstand der Jüdischen Interessenvertretung in Bendsburg (Zarząd Przedstawicielstwa Ludności Żydowskiej w Będzinie) 1939-1945, oprac. Anita Chodkowska, Dorota Zamojska, 2006, sygn. 212.

\section{2. Źródła opublikowane}

Kirschner Ann, Listy z pudełka. Sekret mojej mamy, tłum. z języka angielskiego Barbara Gadomska, tłum. listów z języka jidysz i niemieckiego Aleksandra Geller, Warszawa 2008.

Laskier Rutka, Pamiętnik, red. Adam Szydłowski, Będzin 2008.

Lerchenfeld Anna, Relacja, [w:] Andrzej Strzelecki, Zagłada Żydów z Zagłębia Dąbrowskiego w KL Auschwitz, Oświęcim 2014.

Yahalomi Ariel, Przeżyłem..., wyd. 3, Będzin 2014.

\section{Opracowania}

Czech Danuta, Kalendarz wydarzeń w KL Auschwitz, Oświęcim 1992.

Fontette François de, Historia antysemityzmu, tłum. Maria Mendychowska, Mieczysław Mendychowski, Wrocław 1992.

Hilberg Raul, Zagłada Żydów europejskich, t. 1, tłum. Jerzy Giebułtowski, Warszawa 2014.

Kac Fela, Pozostało jedynie oznaczyć cenę, za która oddać trzeba było życie, „Ekspres Zagłębiowski” (1994), nr 7.

Namysło Aleksandra, Centrala Żydowskich Rad Starszych na Wschodnim Górnym Śląsku, [w:] Zagłada Żydów zagłębiowskich, red. Aleksandra Namysło, Będzin 2004.

Namysło Aleksandra, Postawy mieszkańców rejencji katowickiej wobec ludności żydowskiej, [w:] Polacy i Żydzi pod okupacją niemiecka 1939-1945. Studia i materiały, red. Andrzej Żbikowski, Warszawa 2006.

Namysło Aleksandra, Wpływ kierownictwa Centrali Żydowskich Rad Starszych Wschodniego Górnego Ślaska na postawy i zachowania Żydów wobec rzeczywistości okupacyjnej, [w:] Zagłada Żydów na polskich terenach wcielonych do Rzeszy, red. Aleksandra Namysło, Warszawa 2008. 
Namysło Aleksandra, Zanim nadeszła Zagłada... Położenie ludności żydowskiej w Zagłębiu Dąbrowskim w okresie okupacji niemieckiej / Before the Holocaust Came... The Situation of Jews in Zaglembie during the German Occupation, tłum. Alicja Cholewa-Zawadzka, Jana Dębska, Katowice 2009.

Nirensztain Albert, Ruch oporu Żydów w Zagłębiu Dąbrowskim pod okupacja hitlerowska, „Kwartalnik Historii Żydów” (2001), nr 4.

Oxenhaendler Fredka Mazja, Ronen-Klinger Avihu, Z historii Żydów na Wschodnim Górnym Śląsku. Holocaust w Zagłębiu, „Ekspres Zagłębiowski” (1994), nr $1 / 2$.

Paldiel Mordecai, Saving the Jews: Amazing Stories of Men and Women Who Defied the „Final Solution”, Rockville 2000.

Piper Franciszek, Żydzi w KL Auschwitz, Oświęcim 2015.

Polonsky Antony, Dzieje Żydów w Polsce i Rosji, tłum. Mateusz Wilk, Warszawa 2014.

Schönker Henryk, Dotknięcie anioła, Warszawa 2011.

Starczewska Ewa, Żelechowska Anna, O godne życie i godna śmierć. Izrael Kożuch zapomniany bohater, [w:] Żydzi na Górnym Śląsk i w Zagłębiu Dąbrowskim. Historia, kultura, zagadnienia konserwatorskie, red. Dariusz Rozmus, Sławomir Witkowski, Kraków-Bytom 2011.

Strzelecki Andrzej, Zagłada Żydów z Zagłębia Dąbrowskiego w KL Auschwitz, Oświęcim 2014.

Szternfinkiel Natan Eliasz, Zagłada Żydów z Sosnowca, Katowice 1946.

Szyndler Artur, Leon Schönker i jego plan emigracji Żydów z rejencji katowickiej z końca 1939 r., „Studia Judaica” 12 (2009), nr 1-2.

Urynowicz Marcin, Adam Czerniaków 1880-1942. Prezes getta warszawskiego, Warszawa 2009.

Wolff-Powęska Anna, „Noc kryształowa” - noc hańby, „Znak” 60 (2008), nr 12, http://www.miesiecznik.znak.com.pl/6432008anna-wolff-poweskanoc-krysztalowa-noc-hanby/ [dostęp: 19 marca 2017].

Żbikowski Andrzej, Zagłada Żydów polskich, [w:] Historia Żydów. Dzieje narodu od Abrahama do Państwa Izrael. Żydzi w Polsce. 1000 lat wspólnych losów, red. Leszek Będkowski, Anita Brzostowska, Warszawa 2014.

Maria Misztal Uniwersytet Opolski mariamisztal.1@wp.pl 